\title{
Contribution of litter layer to soil greenhouse gas emissions in a temperate beech forest
}

\author{
Sonja Leitner • Orracha Sae-Tun • Lukas Kranzinger • \\ Sophie Zechmeister-Boltenstern • \\ Michael Zimmermann
}

Received: 17 July 2015 / Accepted: 3 December 2015 / Published online: 6 February 2016

(C) The Author(s) 2016. This article is published with open access at Springerlink.com

\begin{abstract}
Background and aims The litter layer is a major source of $\mathrm{CO}_{2}$, and it also influences soil-atmosphere exchange of $\mathrm{N}_{2} \mathrm{O}$ and $\mathrm{CH}_{4}$. So far, it is not clear how much of soil greenhouse gas (GHG) emission derives from the litter layer itself or is litter-induced. The present study investigates how the litter layer controls soil GHG fluxes and microbial decomposer communities in a temperate beech forest.

Methods We removed the litter layer in an Austrian beech forest and studied responses of soil $\mathrm{CO}_{2}, \mathrm{CH}_{4}$ and $\mathrm{N}_{2} \mathrm{O}$ fluxes and the microbial community via phospholipid fatty acids (PLFA). Soil GHG fluxes were determined with static chambers on 22 occasions from July 2012 to February 2013, and soil samples collected at 8 sampling events.
\end{abstract}

Responsible Editor: Per Ambus.

S. Leitner $(\bowtie) \cdot$ O. Sae-Tun $\cdot$ L. Kranzinger •

S. Zechmeister-Boltenstern • M. Zimmermann

Institute of Soil Research, University of Natural Resources and

Life Sciences Vienna (BOKU), Peter Jordan-Str. 82, 1190 Vienna,

Austria

e-mail: sonja.leitner@boku.ac.at

O. Sae-Tun

Kasetsart Agricultural and Agro-Industrial Product Improvement Institute, Kasetsart University, 50 Ngamwongwan Rd., Ladyao

Chatuchak, Bangkok 10900, Thailand

L. Kranzinger

Department of Environmental and Energy Process Engineering, Montanuniversitaet Leoben, Franz-Josef-Str. 18, 8700 Leoben, Austria
Results Litter removal reduced $\mathrm{CO}_{2}$ emissions by $30 \%$ and increased temperature sensitivity $\left(\mathrm{Q}_{10}\right)$ of $\mathrm{CO}_{2}$ fluxes. Diffusion of $\mathrm{CH}_{4}$ into soil was facilitated by litter removal and $\mathrm{CH}_{4}$ uptake increased by $16 \%$. This effect was strongest in autumn and winter when soil moisture was high. Soils without litter turned from net $\mathrm{N}_{2} \mathrm{O}$ sources to slight $\mathrm{N}_{2} \mathrm{O}$ sinks because $\mathrm{N}_{2} \mathrm{O}$ emissions peaked after rain events in summer and autumn, which was not the case in litter-removal plots. Microbial composition was only transiently affected by litter removal but strongly influenced by seasonality.

Conclusions Litter layers must be considered in calculating forest GHG budgets, and their influence on temperature sensitivity of soil GHG fluxes taken into account for future climate scenarios.

Keywords Litter removal - Seasonality $\cdot \mathrm{CO}_{2} \cdot \mathrm{CH}_{4}$. $\mathrm{N}_{2} \mathrm{O} \cdot$ PLFA

$\begin{array}{ll}\text { Abbreviations } \\ \mathrm{LR} & \text { Litter removal } \\ \mathrm{CO}_{2} & \text { Carbon dioxide } \\ \mathrm{CH}_{4} & \text { Methane } \\ \mathrm{N}_{2} \mathrm{O} & \text { Nitrous oxide } \\ \mathrm{GHG} & \text { Greenhouse gases } \\ \mathrm{SOC} & \text { Soil organic carbon } \\ \mathrm{TN} & \text { Total nitrogen } \\ \mathrm{C}_{\text {mic }} & \text { Microbial carbon } \\ \mathrm{N}_{\text {mic }} & \text { Microbial nitrogen } \\ \mathrm{NH}_{4}{ }^{+} & \text {Ammonium }\end{array}$




$\begin{array}{ll}\mathrm{NO}_{3}{ }^{-} & \text {Nitrate } \\ \mathrm{PO}_{4}{ }^{3-} & \text { Phosphate } \\ \text { WSS } & \text { Water-soluble sugars } \\ \text { VWC } & \text { Soil volumetric water content } \\ \mathrm{T}_{\text {soil }} & \text { Soil temperature } \\ \text { DaLR } & \text { Day after litter removal } \\ \text { PLFA } & \text { Phospholipid fatty acids } \\ \text { gram- } & \text { Gram-negative bacteria } \\ \text { gram+ } & \text { Gram-positive bacteria } \\ \text { Q } & \text { Temperature sensitivity } \\ \text { CCA } & \text { Canonical correspondence analysis }\end{array}$

\section{Introduction}

Forest soils play an important role in controlling global greenhouse gas (GHG) budgets because they act mostly as carbon dioxide $\left(\mathrm{CO}_{2}\right)$ sources, methane $\left(\mathrm{CH}_{4}\right)$ sinks and nitrous oxide $\left(\mathrm{N}_{2} \mathrm{O}\right)$ sources (IPCC 2013). Soil microbial communities strongly influence soil GHG fluxes (Conrad 1996; Schimel and Gulledge 1998), and are typically adapted to the type of plant litter in a certain environment (Ayres et al. 2009; Madritch and Lindroth 2011). Although plant litter contributes the largest input of $\mathrm{C}$ and nutrients to forest soils (FAO 2010), there is a lack of knowledge on the explicit impact of the litter layer on forest soil GHG fluxes. Atmospheric $\mathrm{CO}_{2}$ is the major driver of global warming, and $\mathrm{CH}_{4}$ and $\mathrm{N}_{2} \mathrm{O}$ are potent GHGs with 100-year global warming potentials of 28 and 265 , respectively (IPCC 2013). Partitioning the contribution of litter and mineral soil to total soil GHG fluxes as well as improving our understanding on how the litter layer influences soil processes and microbial communities will help to reduce uncertainties in biogeochemical models and improve our forecasts of future GHG budgets for terrestrial ecosystems. Because ecosystem GHG sinks can be used to a limited extend to compensate for emission reductions stipulated in the Kyoto protocol (IPCC 2014), a precise quantification of ecosystem $\mathrm{C}$ and $\mathrm{N}$ budgets is of utmost importance for climate change mitigation.

Forests cover $31 \%$ of land area and contain $652 \mathrm{GtC}$, $45 \%$ in soils and $11 \%$ in dead wood and litter (FAO 2010). Respiration from plant litter decomposition contributes between 5 and $45 \%$ to total soil $\mathrm{CO}_{2}$ emissions in temperate forests (Borken and Beese 2005; Bowden et al. 1993; Vose and Bolstad 2007). The litterinhabiting microbial community in beech forests is dominated by fungi that can decompose litter cellulose and lignin (Schneider et al. 2012). Removing the litter might decrease the fungi:bacteria $(\mathrm{F}: \mathrm{B})$ ratio in the soil. Because most fungi have a higher $\mathrm{C}$ use efficiency (CUE) than bacteria (Keiblinger et al. 2010), a shift in the $\mathrm{F}: \mathrm{B}$ ratio is likely to affect soil $\mathrm{CO}_{2}$ emissions.

Furthermore, temperate forests are considered to be important $\mathrm{CH}_{4}$ sinks through the consumption of $\mathrm{CH}_{4}$ by methanotrophic bacteria in well-aerated forest soils (Dalal and Allen 2008; Le Mer and Roger 2001). Litter itself does apparently not produce or consume $\mathrm{CH}_{4}$ (Dong et al. 1998; Reith et al. 2002; Smith et al. 2000). However, the litter layer has been reported to influence soil $\mathrm{CH}_{4}$ uptake by controlling gas diffusion into the soil (Peichl et al. 2010; Wang et al. 2013), which can be particularly important in broad-leaved forests like beech (Brumme and Borken 1999). Furthermore, soils that receive high $\mathrm{N}$ loads due to $\mathrm{N}$ fertilization or atmospheric $\mathrm{N}$ deposition often consume less $\mathrm{CH}_{4}$ than undisturbed soils (Butterbach-Bahl et al. 1998; Macdonald et al. 1997; Steudler et al. 1989) because $\mathrm{NH}_{4}{ }^{+}$inhibits oxidation of $\mathrm{CH}_{4}$ to $\mathrm{CO}_{2}$ by methanotrophic bacteria (Bodelier and Laanbroek 2004). However, whether litter $\mathrm{N}$ content influences soil $\mathrm{CH}_{4}$ fluxes, for example via leaching of $\mathrm{N}$ to the mineral soil, remains to be demonstrated.

Soils under natural vegetation are mostly regarded as $\mathrm{N}_{2} \mathrm{O}$ sources and account for 6.6 $\mathrm{Tg} \mathrm{N}_{2} \mathrm{O}-\mathrm{N} \mathrm{yr}^{-1}$ to the global terrestrial $\mathrm{N}_{2} \mathrm{O}$ input to the atmosphere (IPCC 2013). How the litter layer affects soil $\mathrm{N}_{2} \mathrm{O}$ flux is not clear. Dong et al. (1998) reported that removal of leaf litter/humus layer significantly decreased $\mathrm{N}_{2} \mathrm{O}$ emissions in a German deciduous forest, which they attributed primarily to emissions of the humus layer itself. Wieder et al. (2011) found a priming effect of labile C leaching from plant litter on soil $\mathrm{N}_{2} \mathrm{O}$ emissions for tropical ecosystems, which can either be a direct result of stimulation of heterotrophic denitrifiers or occur indirectly by increased heterotrophic $\mathrm{O}_{2}$ consumption and formation of anaerobic microsites in the soil. However, contribution of litter itself to total soil $\mathrm{N}_{2} \mathrm{O}$ emissions in temperate forests as well as the importance of dissolved organic carbon (DOC) leaching from litter to mineral soils is not well studied.

The purpose of the present study was to quantify how much of forest soil GHG flux is litter-induced, as well as to investigate how removal of the aboveground litter layer (henceforth referred to as 'litter removal') influences the soil processes and microbial community 
composition in the short term. We hypothesized that litter removal (i) reduces soil concentrations of mobile $\mathrm{C}, \mathrm{N}$ and $\mathrm{P}$, (ii) reduces soil $\mathrm{CO}_{2}$ efflux, (iii) enhances soil $\mathrm{CH}_{4}$ uptake, (iv) reduces soil $\mathrm{N}_{2} \mathrm{O}$ efflux, and (v) reduces the proportion of fungi in the soil microbial community.

\section{Materials and methods}

Study site

The study was conducted in a pure mature beech forest (Fagus sylvatica L.) at the 'Rosalia Lehrforst' site, which is part of the 'long-term ecological research' network (LTER-Austria) and is located in

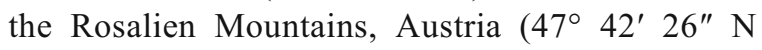
$\left./ 16^{\circ} 17^{\prime} 59^{\prime \prime} \mathrm{E}\right)$. The soil at the study site was a pseudo-gleyic Cambisol over metamorphic crystalline bedrock. Mean annual temperature and mean annual precipitation were $6.5^{\circ} \mathrm{C}$ and $796 \mathrm{~mm}$, respectively. The study site was at an elevation of $600 \mathrm{~m}$ asl and exposed to the west.

\section{Experimental design}

Twelve pairs of experimental plots were randomly positioned along a $20 \mathrm{~m}$ horizontal line, each consisting of one control and one litter-removal (LR) plot. The litter layer was removed carefully by hand in an area of $0.5 \mathrm{~m} \times 0.5 \mathrm{~m}$ from the LR plots in June 2012. Total removed litter accounted for $1.39 \mathrm{~kg} \mathrm{dw} \mathrm{m}^{-2}$, which contained $0.55 \mathrm{~kg} \mathrm{C} \mathrm{m}^{-2}$. The bare mineral soil was covered with a black water-permeable textile mat to prevent excessive soil-drying due to litter removal, which allowed us to focus on the influence of nutrient leaching from the litter rather than changes in soil microclimate. A metal mesh cage $(25 \mathrm{~cm}$ height $)$ was placed over the LR plots to prevent new litter input. On all 24 plots, PVC collars of $20 \mathrm{~cm}$ diameter and $10 \mathrm{~cm}$ height were inserted carefully $2-3 \mathrm{~cm}$ into the ground to be used as closed headspace chambers to collect air samples. Between July 2012 and February 2013 air samples were collected 22 times and soil samples 8 times. Microbial community composition was determined via phospholipid fatty acid (PLFA) analysis at 5 time points.
Soil analysis

Soil samples were collected from all 24 plots with metal cylinders of $4 \mathrm{~cm}$ diameter and $5 \mathrm{~cm}$ height. At each sampling, 5 soil cores from each plot were taken and pooled together. Before soil cores were taken from control plots, the litter layer was carefully moved aside locally and only mineral soil was sampled to make soil samples from control plots comparable to those from LR plots. At the same time, soil temperature in $5 \mathrm{~cm}$ depth was determined with a penetration thermometer (Voltcraft DET3R, Switzerland), and volumetric water content (VWC) was measured with a TDR probe (SM300, Delta-T, UK). Soil samples were transported to the laboratory in Vienna, sieved $(<2 \mathrm{~mm})$ and stored at $4{ }^{\circ} \mathrm{C}$ for nutrient and microbial biomass analysis, and at $-18{ }^{\circ} \mathrm{C}$ for PLFA analysis. All soil samples were analyzed for $\mathrm{pH}, \mathrm{NO}_{3}{ }^{-}, \mathrm{NH}_{4}{ }^{+}, \mathrm{PO}_{4}{ }^{3-}$, water-soluble sugars (WSS), microbial biomass, and soil organic $\mathrm{C}$ (SOC) and total nitrogen (TN) contents. Soil pH was determined with a calibrated pH-meter (WTW 537, Germany) in a suspension of $2 \mathrm{~g}$ fresh soil in $25 \mathrm{ml}$ $0.01 \mathrm{M} \mathrm{CaCl}_{2}$ (Schinner et al. 1996). Nitrate, $\mathrm{NH}_{4}{ }^{+}$and $\mathrm{PO}_{4}{ }^{3-}$ concentrations were measured in suspensions of $5 \mathrm{~g}$ fresh soil in $50 \mathrm{ml} 1 \mathrm{M} \mathrm{KCl}$ with a photometer (Perkin Elmer 2300 EnSpire, USA) as described elsewhere (Hood-Nowotny et al. 2010; Schinner et al. 1996). Hot-water soluble reducing sugars (WSS) were detected with the Prussian-blue method (Schinner and Von Mersi 1990; Slaughter et al. 2001). Microbial biomass carbon $\left(\mathrm{C}_{\text {mic }}\right)$ and nitrogen $\left(\mathrm{N}_{\text {mic }}\right)$ of the samples was calculated as difference of DOC and total dissolved nitrogen (TDN), respectively, before and after chloroform fumigation (Schinner et al. 1996). Soil organic C and $\mathrm{TN}$ were quantified on oven-dried $\left(105^{\circ} \mathrm{C}\right)$ soil with an elemental analyzer (NA-1500 Carlo Erba, Italy). Additionally, the textile mat was tested for leaching of $\mathrm{C}, \mathrm{N}$ and $\mathrm{P}$, and no leaching was detected.

Soil greenhouse gas fluxes

To collect gas samples, the 24 dark chambers (total volume $2.51 \mathrm{~L}$ ) were closed with air-tight lids and gas samples were collected with a syringe through a rubber septum in the lid $0,10,20$ and $60 \mathrm{~min}$ after chamber closure. $30 \mathrm{ml}$ gas samples were injected into $20 \mathrm{ml}$ preevacuated glass vials (clear flat-bottom headspace vials with aluminum crimp caps and grey butyl septa, all from Agilent Technologies, Austria) and transported to the 
lab. Gas samples were stored at air temperature and analyzed within 1 week. Concentrations of $\mathrm{CO}_{2}, \mathrm{CH}_{4}$ and $\mathrm{N}_{2} \mathrm{O}$ of all gas samples were determined with an Agilent GC-system (Agilent Technologies). Detector 1 was an electron capture detector (ECD) for $\mathrm{N}_{2} \mathrm{O}$ measurements, and detector 2 was a flame ionization detector (FID) with Ni-methanizer to quantify $\mathrm{CO}_{2}$ and $\mathrm{CH}_{4}$ (all Agilent Technologies, Austria). For calibration, gas mixes of $\mathrm{CO}_{2}, \mathrm{CH}_{4}$ and $\mathrm{N}_{2} \mathrm{O}$ in $\mathrm{N}_{2}$-gas in 3 different concentrations $\left(\mathrm{CO}_{2} 250,500,1000 \mathrm{ppm} ; \mathrm{CH}_{4}\right.$ 1, 2, 4 ppm; $\mathrm{N}_{2} \mathrm{O} 0.5,2.5,5$ ppm, respectively) were used (Linde Gas, Austria). Limit of detection (LoD) of the chamber measurements was $3.6 \mathrm{mg} \mathrm{CO}_{2}-\mathrm{C} \mathrm{m}^{-2} \mathrm{~h}^{-1}$, $9.2 \mu \mathrm{g} \mathrm{CH}_{4}-\mathrm{C} \mathrm{m}^{-2} \mathrm{~h}^{-1}$ and $10.1 \mu \mathrm{g} \mathrm{N} \mathrm{N}_{2} \mathrm{O}-\mathrm{N} \mathrm{m}^{-2} \mathrm{~h}^{-1}$, respectively (Parkin et al. 2012). Because $\mathrm{N}_{2} \mathrm{O}$ fluxes from temperate forest soils are known to be highly variable in time and space, with high fluxes during "hot moments" such as drying-rewetting or freeze-thaw events, and low fluxes during the rest of the year (Groffman et al. 2009). Therefore, in the present study fluxes below the LoD were not excluded from the calculation of average fluxes over the study period, because this would have caused a bias towards higher emissions. Nevertheless, the reader should be aware that values below LoD bear a high analytical uncertainty.

Hourly GHG flux rates for each chamber were calculated based on Eq. (1) as described by Metcalfe et al. (2007),

GHG flux $=\Delta \mathrm{C} / \Delta \mathrm{t}^{*} 273.15 /\left(\mathrm{T}_{\text {air }}+273.15\right) * \mathrm{p} / 1000 * \mathrm{M} / 22.41 * \mathrm{~V} / \mathrm{A}$

Where GHG flux is the flux of the respective greenhouse gas, $\Delta C / \Delta t$ is the concentration change (ppm for $\mathrm{CO}_{2}$, ppb for $\mathrm{CH}_{4}$ and $\mathrm{N}_{2} \mathrm{O}$ ) over time (h), $T_{\text {air }}$ is air temperature $\left({ }^{\circ} \mathrm{C}\right), p$ is atmospheric pressure $(\mathrm{Pa}), M$ is molecular weight $(\mathrm{g}), 22.41$ is the molar volume of an ideal gas at Standard Temperature and Pressure $\left(1 \mathrm{~mol}^{-1}\right), V$ is the chamber volume $\left(\mathrm{m}^{3}\right)$ and $A$ the chamber area $\left(\mathrm{m}^{2}\right)$. The term $\left(\mathrm{T}_{\text {air }}+273.15\right)$ is used to convert air temperature from degree Celsius to Kelvin. For calculation of $\mathrm{CO}_{2}$ and $\mathrm{CH}_{4}$ fluxes, $M$ is $12.01 \mathrm{~g}$ (the molecular weight of C) and units are $\mathrm{mg} \mathrm{CO} \mathrm{CO}_{2}-\mathrm{C} \mathrm{h}^{-1} \mathrm{~m}^{-2}$ and $\mu \mathrm{g} \mathrm{CH}_{4}-\mathrm{C}$ $\mathrm{h}^{-1} \mathrm{~m}^{-2}$, respectively. For calculation of $\mathrm{N}_{2} \mathrm{O}$ flux, $M$ is $28.02 \mathrm{~g}$ (the molecular weight of $2 \mathrm{~N}$ atoms) and units are $\mu \mathrm{g} \mathrm{N} \mathrm{N}_{2} \mathrm{O}-\mathrm{N} \mathrm{h}^{-1} \mathrm{~m}^{-2}$. Concentration changes over time were determined with quadratic best-fit equations for $\mathrm{CO}_{2}$ and $\mathrm{N}_{2} \mathrm{O}$, and an exponential best-fit equation for $\mathrm{CH}_{4}$. Greenhouse gas fluxes were discharged if regression coefficients $\left(\mathrm{r}^{2}\right)$ were below 0.70 for $\mathrm{CH}_{4}$ and $\mathrm{N}_{2} \mathrm{O}$, and below 0.90 for $\mathrm{CO}_{2}$ (Barton et al. 2008; Chadwick et al. 2014; Unteregelsbacher et al. 2013). Positive fluxes represent net GHG emissions, negative fluxes represent net GHG uptake. Greenhouse gas fluxes of control and LR plots were averaged for each sampling event and are given together with standard errors ( $n=12$ per treatment). Litter-induced GHG flux was calculated as the difference between GHG flux from control plots (soil \& litter) and LR plots (soil only):

Litter-induced GHG flux $=$ GHG flux control $-\mathrm{GHG}_{\text {flux }} \mathrm{LR}$

Temperature sensitivity values $\left(\mathrm{Q}_{10}\right)$ were calculated for soil GHG fluxes that were significantly correlated with soil temperature after a Lloyd \& Taylor function (Eq. 3) according to Tuomi et al. (2008):

GHG flux $=\mathrm{a} * \exp \left((\mathrm{E} /(283.15 * 8.314)) *\left(1-283.15 /\left(\mathrm{T}_{\text {soil }}+273.15\right)\right)\right)$

with $a$ and $E$ as fitted parameters, $T_{\text {soil }}$ the soil temperature $\left({ }^{\circ} \mathrm{C}\right)$, which is converted to Kelvin by adding $273.15,8.314$ is the universal gas constant $\left(\mathrm{J} \mathrm{mol}^{-1}\right.$ $\mathrm{K}^{-1}$ ), and 283.15 is some reference temperature $\left(10^{\circ} \mathrm{C}\right.$, see also Lloyd and Taylor 1994).

Phospholipid fatty acid (PLFA) analysis

Phospholipid fatty acids were analyzed in pooled soil samples for reasons of feasibility (from the 12 soil samples per treatment, 4 were combined to one composite sample, which resulted in 3 composite samples per treatment and time point). Phospholipid fatty acids were extracted after an adapted protocol of the Bligh and Dyer method (Frostegård et al. 1991) as described elsewhere (Brandstätter et al. 2013; Djukic et al. 2010). Briefly, $2 \mathrm{~g}$ field-moist soil were extracted overnight in the dark with chloroform:methanol:citrate buffer (1:2:0.8) and chloroform:methanol (1:2), fractionated by sequential elution with chloroform, acetone and methanol on silica solid-phase columns (Isolute SI

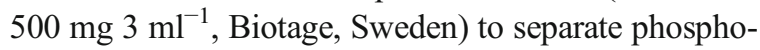
lipids from neutral lipid fatty acids and glycolipids. Samples were methylated with methanol:toluol (1:1), $0.2 M$ methanolic $\mathrm{KOH}$ and $1 M$ acetic acid. Phospholipids where re-dissolved in $200 \mu$ iso-octane and analyzed with an HP 6980 series GC-system and 7683 series injector and auto-sampler on an HP-5 $50 \mathrm{~m}$ 
capillary column (all Hewlett Packard, USA) using a flame ionization (FID) detector. A mix of bacterial acid methyl esters (Supelco BAME CP Mix \# 47080-U, Sigma-Aldrich, USA) was used as qualitative standard to identify PLFAs. Concentrations of individual PLFAs were quantified relative to the internal standard nonadecanoate fatty acid (19:0, $\left.20 \mathrm{mg} \mathrm{l}^{-1}\right)$.

Absolute amounts of PLFAs are given in $\mu$ mol PLFA $\mathrm{g}^{-1}$ SOC. The PLFAs i14:0, i15:0, a15:0, i16:0, i17:0, a17:0 and 10Me18:0 were used as markers for gram +

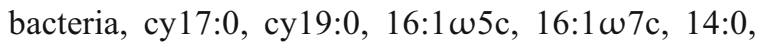
15:0, 17:0 for gram- bacteria, $10 \mathrm{Me} 16: 0$ and

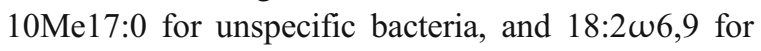
fungi (Baath 2003; Djukic et al. 2010, 2013; Zelles 1999). Total bacterial PLFAs were calculated from the sum of gram+, gram- and unspecific bacterial markers. Bacteria:fungi ratio was calculated as the sum of bacte-

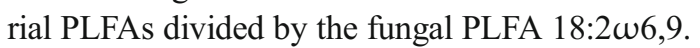

\section{Statistical analysis}

To identify effects of time and litter removal, first a two-way ANOVA was used to check for interactions between factors. If interactions were found, the dataset was split into control and LR subsets, and one-way ANOVA followed by Tukey's post hoc test was employed to identify differences between time points. Differences between treatments were analyzed by separate $t$-tests for each time point. Homogeneity of variance was tested with Levene's test, and data were log-transformed if necessary. If transformation did not ensure homogeneity of variance, robust ANOVA as described by Wilcox (2005) was employed. Microbial community composition was analyzed by canonical correspondence analysis (CCA), using the mole percentage of PLFAs as community matrix and soil parameters and time as constraining factors. Interactions between soil GHG fluxes and soil temperature and moisture were analyzed on data from 22 gas samplings by Spearman's rank correlation with Benjamini \& Hochberg correction to test for false positives (type I error) in multiple comparisons (Benjamini and Hochberg 1995). Statistical analysis was conducted with Statgraphics (StatPoint Technologies, United States), SigmaPlot (Systat Software, USA), and R 3.0.2 using packages "vegan" for CCA (Oksanen et al. 2014) and "WRS" for robust ANOVA (Wilcox 2005).

\section{Results}

Soil properties

Average soil temperatures were $11.2 \pm 1.4{ }^{\circ} \mathrm{C}$ and 11.1 $\pm 1.4{ }^{\circ} \mathrm{C}$ between July 2012 and February 2013 for control and LR plots, respectively, and were not significantly altered by litter removal (Fig. 1a). Soil temperature changed according to seasons and decreased from $18^{\circ} \mathrm{C}$ during July and August to $2-5^{\circ} \mathrm{C}$ in December to February. Volumetric soil water content (Fig. 1a), which averaged $22.4 \pm 1.8 \%$ and $23.5 \pm 2.1 \%$ for control and LR plots, respectively, was also not significantly affected by litter removal and increased from July to February, with a large peak in the first 2 weeks of August 2012 due to strong rainfall events. Soils at our site were strongly acidic with a mean soil $\mathrm{pH}$ of $3.9 \pm 0.1$, which was not affected by litter removal. Bulk density was 0.595 $\pm 0.143 \mathrm{~g} \mathrm{~m}^{-3}$.

Soil nutrients were only affected by litter removal at the start of the experiment (Table 1). One week after removing the litter layer, $\mathrm{NH}_{4}{ }^{+}$increased by $134 \%$ from $302 \pm 26 \mathrm{mg} \mathrm{N} \mathrm{m}^{-2}$ in controls to $710 \pm 20 \mathrm{mg} \mathrm{N} \mathrm{m}^{-2}$ in LR plots. Stocks of SOC $\left(2.1 \pm 0.24 \mathrm{~kg} \mathrm{C} \mathrm{m}^{-2}\right)$ and TN $\left(0.11 \pm 0.01 \mathrm{~kg} \mathrm{~N} \mathrm{~m}^{-2}\right)$ in the uppermost $5 \mathrm{~cm}$ were not influenced by litter removal. At the consecutive samplings, concentrations of $\mathrm{NO}_{3}{ }^{-}, \mathrm{NH}_{4}{ }^{+}, \mathrm{PO}_{4}{ }^{3-}$ and WSS did not differ between treatments (Table 2).

Soil greenhouse gas fluxes

Litter removal significantly decreased $\mathrm{CO}_{2}$ fluxes from soil by $29.9 \%$ (Fig. 1b, Table 2). On average, control plots emitted $128 \pm 13 \mathrm{mg} \mathrm{CO}_{2}-\mathrm{C} \mathrm{h}^{-1} \mathrm{~m}^{-2}$, whereas LR plots respired $90 \pm 10 \mathrm{mg} \mathrm{CO}-\mathrm{C} \mathrm{h}^{-1} \mathrm{~m}^{-2}$. Soil $\mathrm{CO}_{2}$ fluxes of both control and LR plots followed the seasonal trend of soil temperature and decreased from July to February. Absolute litter-induced $\mathrm{CO}_{2}$ fluxes (difference between control and LR plots) decreased from July 2012 to February 2013, and relative contribution of litter-induced to total soil $\mathrm{CO}_{2}$ efflux ranged from 15.6 to $46.1 \%$.

The forest soil acted as atmospheric $\mathrm{CH}_{4}$ sink during the entire study period (Fig. 1c). Litter removal significantly increased soil $\mathrm{CH}_{4}$ uptake by $16.0 \%$ (i.e., $\mathrm{CH}_{4}$ fluxes were $16.0 \%$ more negative) with average $\mathrm{CH}_{4}$ uptakes of $40.0 \pm 2.3 \mu \mathrm{g} \mathrm{CH}_{4}-\mathrm{C} \mathrm{h}^{-1} \mathrm{~m}^{-2}$ in control plots and $46.4 \pm 2.6 \mu \mathrm{g} \mathrm{CH}_{4}-\mathrm{C} \mathrm{h}^{-1} \mathrm{~m}^{-2}$ in LR plots. Differences between control and LR plots where large 
Fig. 1 a, soil temperature $\left(\mathrm{T}_{\text {soil }}\right.$, solid line) and soil volumetric water content (VWC, dashed line) in the experimental plots; b-d, total greenhouse gas (GHG) flux from control $(\bullet)$ and litterremoval $(\nabla)$ plots as well as litterinduced GHG flux ( $(\circ)$ and contribution of litter-induced to total GHG flux (grey bars) (mean $\pm \mathrm{SE}, \mathrm{n}=12)$ : b, $\mathrm{CO}_{2} ; \mathbf{c}, \mathrm{CH}_{4} ; \mathbf{d}$, $\mathrm{N}_{2} \mathrm{O}$. Limit of Detection (LoD, dotted line) of the used GC system was $3.6 \mathrm{mg} \mathrm{CO}_{2}-\mathrm{C} \mathrm{m}^{-2}$ $\mathrm{h}^{-1}, 9.2 \mu \mathrm{g} \mathrm{CH}_{4}-\mathrm{C} \mathrm{m}^{-2} \mathrm{~h}^{-1}$ and $10.1 \mu \mathrm{g} \mathrm{N}_{2} \mathrm{O}-\mathrm{N} \mathrm{m}^{-2} \mathrm{~h}^{-1}$, respectively. Positive fluxes $\left(\mathrm{CO}_{2}\right.$ and $\mathrm{N}_{2} \mathrm{O}$ ) indicate soil $\mathrm{GHG}$ emissions, negative fluxes $\left(\mathrm{CH}_{4}\right.$ and $\mathrm{N}_{2} \mathrm{O}$ ) indicate soil $\mathrm{GHG}$ uptake. Litter-induced flux was calculated as difference between average control and litter-removal GHG fluxes, therefore no standard errors are given

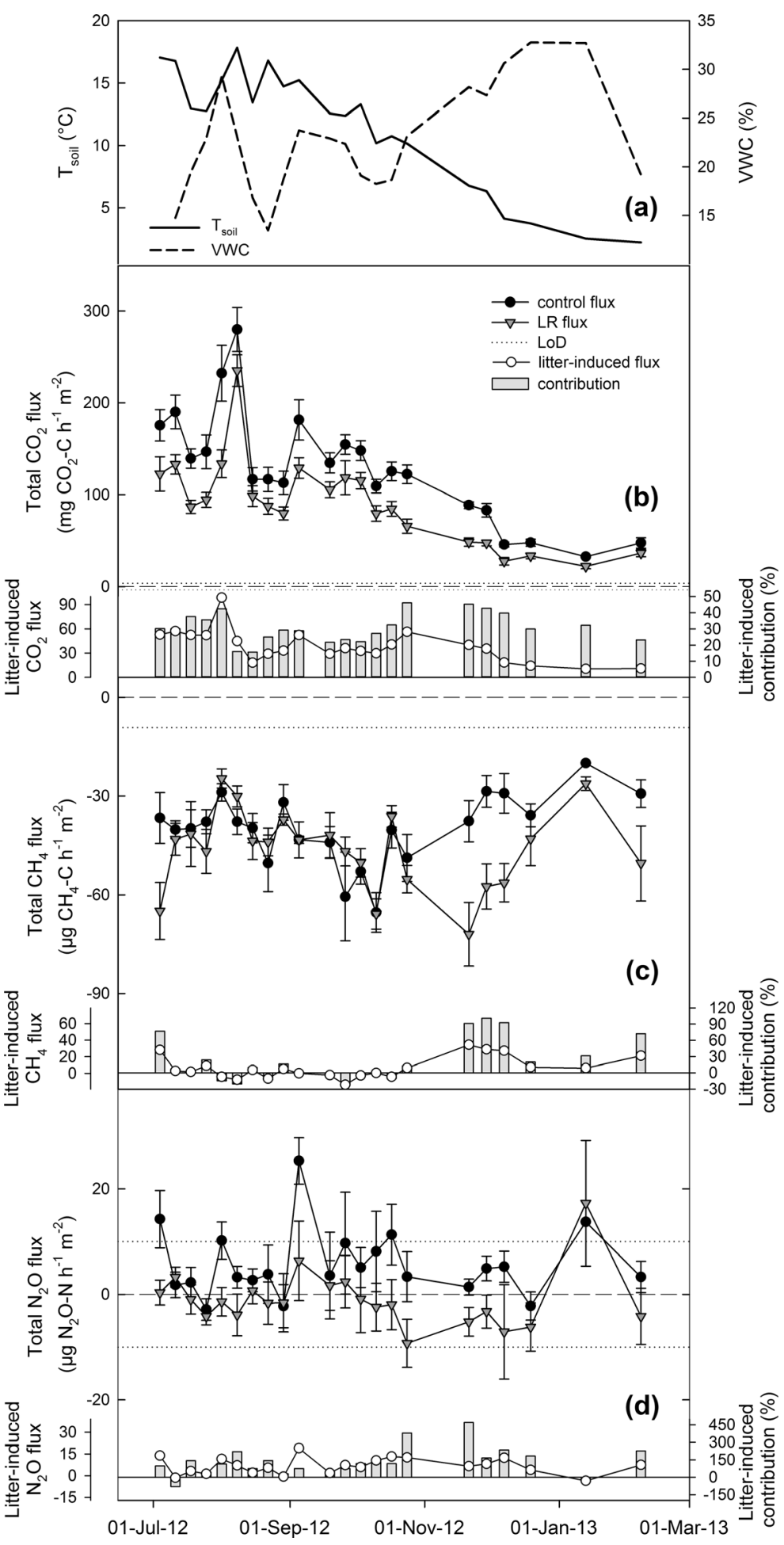

at the beginning of the experiment and in the time from November 2012 to February 2013, with highest absolute litter-induced $\mathrm{CH}_{4}$ fluxes of $28.2 \mu \mathrm{g} \mathrm{CH}_{4}-\mathrm{C} \mathrm{h}^{-1} \mathrm{~m}^{-2}$ in
July 2012 and $34.3 \mu \mathrm{g} \mathrm{CH} \mathrm{CH}_{4}-\mathrm{C} \mathrm{h}^{-1} \mathrm{~m}^{-2}$ in November 2012, which correspond to a 76.8 and $100.9 \%$ increase in $\mathrm{CH}_{4}$ uptake, respectively, if the litter layer was 
Table 1 Soil chemical properties of the uppermost $5 \mathrm{~cm}$ from July 2012 until February 2013 in control and litter-removal (LR) plots

\begin{tabular}{|c|c|c|c|c|c|c|c|c|c|c|c|c|c|}
\hline \multirow{2}{*}{$\begin{array}{l}\text { Date } \\
\text { 02-Jul-12 }\end{array}$} & \multirow[b]{2}{*}{ control } & \multicolumn{2}{|c|}{$\mathrm{C}_{\text {mic }}\left(\mathrm{g} \mathrm{C} \mathrm{m}^{-2}\right)$} & \multicolumn{2}{|c|}{$\mathrm{N}_{\text {mic }}\left(\mathrm{g} \mathrm{N} \mathrm{m}^{-2}\right)$} & \multicolumn{2}{|c|}{$\mathrm{NO}_{3}{ }^{-}\left(\mathrm{mg} \mathrm{N} \mathrm{m}{ }^{-2}\right)$} & \multicolumn{2}{|c|}{$\mathrm{NH}_{4}^{+}\left(\mathrm{mg} \mathrm{N} \mathrm{m}^{-2}\right)$} & \multicolumn{2}{|c|}{$\mathrm{PO}_{4}{ }^{3-}\left(\mathrm{mg} \mathrm{P} \mathrm{m}{ }^{-2}\right)$} & \multicolumn{2}{|c|}{$\begin{array}{l}\text { WSS (mg } \\
\text { Glc-equ m }{ }^{-2} \text { ) }\end{array}$} \\
\hline & & $27.0^{\mathrm{a}}$ & \pm 2.3 & 4.3 & \pm 0.4 & 387 & \pm 111 & $302^{a}$ & \pm 25 & 42.5 & \pm 11.2 & 29.3 & \pm 3.7 \\
\hline & LR & $46.6^{b}$ & \pm 8.2 & 8.0 & \pm 1.8 & 470 & \pm 128 & $710^{b}$ & \pm 20 & 53.2 & \pm 10.8 & 33.8 & \pm 3.9 \\
\hline \multirow[t]{2}{*}{ 15-Jul-12 } & control & 28.5 & \pm 4.0 & 8.2 & \pm 0.8 & 124 & \pm 40 & 225 & \pm 28 & 59.6 & \pm 12.5 & 43.0 & \pm 3.6 \\
\hline & LR & 24.7 & \pm 4.7 & 7.1 & \pm 0.8 & 126 & \pm 42 & 284 & \pm 21 & 55.6 & \pm 8.9 & 36.6 & \pm 3.4 \\
\hline \multirow[t]{2}{*}{ 30-Jul-12 } & control & 39.8 & \pm 6.1 & 5.8 & \pm 1.1 & 628 & \pm 230 & 449 & \pm 49 & 59.7 & \pm 8.2 & 42.7 & \pm 3.9 \\
\hline & LR & 30.5 & \pm 3.1 & 4.2 & \pm 0.5 & 284 & \pm 97 & 393 & \pm 45 & 46.8 & \pm 3.5 & 39.8 & \pm 3.6 \\
\hline \multirow[t]{2}{*}{ 20-Aug-12 } & control & 39.2 & \pm 3.7 & 5.8 & \pm 0.7 & 489 & \pm 140 & 336 & \pm 26 & 44.9 & \pm 5.7 & 19.8 & \pm 1.8 \\
\hline & LR & 39.6 & \pm 5.4 & 6.2 & \pm 1.0 & 332 & \pm 86 & 402 & \pm 42 & 49.0 & \pm 8.4 & 19.7 & \pm 2.0 \\
\hline \multirow[t]{2}{*}{ 24-Sep-12 } & control & 43.3 & \pm 4.5 & 4.7 & \pm 0.7 & 427 & \pm 210 & 342 & \pm 35 & 43.1 & \pm 4.8 & 16.0 & \pm 1.1 \\
\hline & LR & 43.8 & \pm 4.9 & 5.1 & \pm 0.7 & 283 & \pm 90 & 345 & \pm 42 & 40.6 & \pm 4.6 & 15.1 & \pm 1.4 \\
\hline \multirow[t]{2}{*}{ 15-Oct-12 } & control & 48.6 & \pm 6.2 & 4.8 & \pm 1.0 & 431 & \pm 116 & 365 & \pm 52 & 32.3 & \pm 3.7 & 13.2 & \pm 1.2 \\
\hline & LR & 56.7 & \pm 5.2 & 6.7 & \pm 0.9 & 467 & \pm 107 & 372 & \pm 31 & 30.8 & \pm 5.7 & 11.2 & \pm 1.0 \\
\hline \multirow[t]{2}{*}{ 05-Dec-12 } & control & 38.6 & \pm 5.0 & 6.4 & \pm 0.8 & 17.1 & \pm 5.0 & 127 & \pm 10 & 49.7 & \pm 6.1 & 27.1 & \pm 3.7 \\
\hline & LR & 34.9 & \pm 2.9 & 5.7 & \pm 0.5 & 12.7 & \pm 8.1 & 106 & \pm 7 & 37.6 & \pm 3.3 & 21.8 & \pm 2.5 \\
\hline \multirow[t]{2}{*}{ 05-Feb-13 } & control & 38.3 & \pm 3.2 & 6.2 & \pm 0.6 & 182 & \pm 65 & 273 & \pm 39 & 35.3 & \pm 3.7 & 22.8 & \pm 1.9 \\
\hline & LR & 35.9 & \pm 3.6 & 5.9 & \pm 0.6 & 94.5 & \pm 27.2 & 256 & \pm 27 & 28.7 & \pm 4.1 & 19.0 & \pm 1.8 \\
\hline
\end{tabular}

$C_{\text {mic }}$ and $N_{\text {mic }}$ microbial carbon and nitrogen, WSS water-soluble sugars (mg Glucose-equivalents $\mathrm{m}^{-2}$ )

Data are means $\pm \mathrm{SE}$ with $n=12$ for each treatment. Bold values indicate significant difference between treatments $(t$-test; $P<0.05)$

Table 2 Results from two-way ANOVA showing effects of time and litter removal on soil gas fluxes, soil parameters, and microbial groups detected by phospholipid fatty acid (PLFA) analysis. $T_{\text {soil }}$ soil temperature at $5 \mathrm{~cm}, V W C$ soil volumetric water content, $C_{m i c}$ microbial carbon, $N_{\text {mic }}$ microbial nitrogen, WSS water-soluble sugars

\begin{tabular}{|c|c|c|c|c|c|c|}
\hline & \multicolumn{2}{|l|}{ Time } & \multicolumn{2}{|c|}{ Litter removal } & \multicolumn{2}{|c|}{ Time $\mathrm{x}$ Litter removal } \\
\hline & $\mathrm{F}$ & $\mathrm{p}$ & $\mathrm{F}$ & $\mathrm{p}$ & $\mathrm{F}$ & $\mathrm{p}$ \\
\hline $\mathrm{CO}_{2}$ & 51.3 & $* * *$ & 146 & $* * *$ & 0.95 & ns \\
\hline $\mathrm{CH}_{4}$ & 4.71 & $* * *$ & 12.4 & $* * *$ & 2.27 & $* *$ \\
\hline $\mathrm{N}_{2} \mathrm{O}$ & 1.92 & $*$ & 22.8 & $* * *$ & 0.62 & $\mathrm{~ns}$ \\
\hline $\mathrm{T}_{\text {soil }}$ & 107649 & $* * *$ & 0.02 & ns & 46.2 & $* * *$ \\
\hline VWC & 52.8 & $* * *$ & 2.91 & ns & 0.51 & $\mathrm{~ns}$ \\
\hline $\mathrm{C}_{\text {mic }}$ & 4.72 & $* * *$ & 0.26 & ns & 1.73 & ns \\
\hline $\mathrm{N}_{\text {mic }}$ & 1.92 & ns & 0.67 & ns & 2.00 & ns \\
\hline $\mathrm{NO}_{3}^{-}$ & 108 & $* * *$ & 0.01 & ns & 4.97 & $\mathrm{~ns}$ \\
\hline $\mathrm{NH}_{4}^{+}$ & 24.7 & $* * *$ & 2.45 & ns & 2.31 & $*$ \\
\hline $\mathrm{PO}_{4}{ }^{3-}$ & 21.9 & $*$ & 0.16 & ns & 5.20 & ns \\
\hline WSS & 2.45 & $*$ & 0.38 & ns & 1.41 & $\mathrm{~ns}$ \\
\hline $\mathrm{pH}$ & 5.33 & $* * *$ & 0.09 & ns & 2.10 & $*$ \\
\hline Total PLFAs & 2.20 & ns & 0.50 & ns & 3.49 & $*$ \\
\hline Gram + bacteria & 1.36 & ns & 0.68 & ns & 3.18 & $*$ \\
\hline Gram- bacteria & 2.36 & ns & 0.15 & ns & 4.06 & $*$ \\
\hline Fungi & 3.28 & $*$ & 0.32 & ns & 0.59 & ns \\
\hline
\end{tabular}

Soil gas fluxes and soil parameters, $n=12$; microbial groups, $n=3$. Asterisks indicate levels of significance (ns, not significant; * $P<0.05$; **, $P<0.01$ ***,$P<0.001$ ) 
removed. At the other sampling dates between July and October 2012, soil $\mathrm{CH}_{4}$ uptake was of similar magnitude in control and LR plots.

Average $\mathrm{N}_{2} \mathrm{O}$ fluxes were $117.5 \%$ lower in LR than control plots (Fig. 1d), with control plots acting as $\mathrm{N}_{2} \mathrm{O}$ sources $\left(5.72 \pm 1.38 \mu \mathrm{g} \mathrm{N} \mathrm{N}_{2} \mathrm{O}-\mathrm{N} \mathrm{h}^{-1} \mathrm{~m}^{-2}\right.$ ), while LR led to an uptake of atmospheric $\mathrm{N}_{2} \mathrm{O}$ of $1.00 \pm 1.16 \mu \mathrm{g} \mathrm{N} \mathrm{N}_{2} \mathrm{O}-\mathrm{N} \mathrm{h}^{-1} \mathrm{~m}^{-2}$. However, soils under both treatments switched between being $\mathrm{N}_{2} \mathrm{O}$ sources and $\mathrm{N}_{2} \mathrm{O}$ sinks during the study period. In control plots, we observed three $\mathrm{N}_{2} \mathrm{O}$ emission peaks on 01-Aug-2012, 05-Sep-2012 and 17-Oct2012, where VWC had rapidly increased after periods of dry conditions. Although VWC was similar in LR plots on these dates, $\mathrm{N}_{2} \mathrm{O}$ fluxes did not increase. Furthermore, on 13-Jan-2013 high $\mathrm{N}_{2} \mathrm{O}$ emissions were detected in both treatments under a thin snow and ice cover $(\sim 1 \mathrm{~cm})$. On the other sampling dates, $\mathrm{N}_{2} \mathrm{O}$ fluxes were below the LoD (Fig. 1d).

Carbon dioxide fluxes were positively correlated with soil temperature in both treatments (control: $r=0.86, P<0.01$; LR: $r=0.84, P<0.01)$ and negatively correlated with VWC in LR plots $(r=-0.51, P<0.05)$. Methane fluxes were positively related to VWC only in control plots $(r=0.53, P<0.05)$, whereas $\mathrm{N}_{2} \mathrm{O}$ fluxes did not reveal any significant correlations with soil temperature or VWC. Soil temperature and VWC were negatively correlated over the study period in both control and LR plots (both $r=-0.64, P<0.01$ ).

Temperature sensitivities of $\mathrm{CO}_{2}$ fluxes $\left(\mathrm{Q}_{10}\right.$, Fig. 2) decreased with increasing soil temperature in both treatments. At $11^{\circ} \mathrm{C}$, which was the mean soil temperature during the study period, the $\mathrm{Q}_{10}$ calculated from $\mathrm{CO}_{2}$ fluxes at 11 and $21^{\circ} \mathrm{C}$ was $2.45 \pm 0.07$ in control plots and $2.86 \pm 0.09$ in LR plots. Calculated over the observed $\mathrm{T}_{\text {soil }}$ range $\left(4-18{ }^{\circ} \mathrm{C}\right)$, removing the litter significantly increased $\mathrm{Q}_{10}$ values (t-test, $t=-13.7$, $p<0.001)$.

Soil microbial community composition

One week after removing the litter layer, $\mathrm{C}_{\mathrm{mic}}$ increased by $72.6 \%$ due to litter removal (Table 1 ). At all following sampling dates, $\mathrm{C}_{\mathrm{mic}}$ in LR plots was not significantly different from controls. Furthermore, seasonal changes of $\mathrm{C}_{\text {mic }}$ were observed, with highest values in October, whereas $\mathrm{N}_{\text {mic }}$ was relatively stable throughout the study period.

Similarly to $\mathrm{C}_{\text {mic }}$, the total sum of microbial PLFAs was affected by litter removal at the first sampling date and increased by $37.3 \% 1$ week after litter removal (Fig. 3). On this date, PLFA markers for gram + $(+36.9 \%)$ and gram- $(+30.9 \%)$ bacteria were also significantly increased in LR plots. At the other samplings dates, no significant differences between treatments were found. However, seasonal changes in PLFA groups were detected in control plots, with highest concentrations of bacterial PLFA markers in August and February and lowest concentrations in July. The fungal PLFA marker 18:2w6,9 constantly increased from July to February.

The influence of environmental parameters on total microbial community variation as expressed
Fig. $2 \mathrm{CO}_{2}$ flux (mean $\pm \mathrm{SE}$, $n=12)$ in control $(\bullet)$ and litterremoval $(\nabla)$ plots, and temperature sensitivity $\left(\mathrm{Q}_{10}\right)$ of $\mathrm{CO}_{2}$ flux in control (black solid line) and litter-removal (grey dashed line) plots. Relationship between $\mathrm{CO}_{2}$ flux and $\mathrm{T}_{\text {soil }}$ was best described by a Lloyd \& Taylor (F\&T) function $\left(\mathrm{r}^{2}=0.74\right.$, $P<0.001$ for control plots, black dashed-dotted line $; \mathrm{r}^{2}=0.73$, $P<0.001$ for litter-removal plots, grey dotted line)

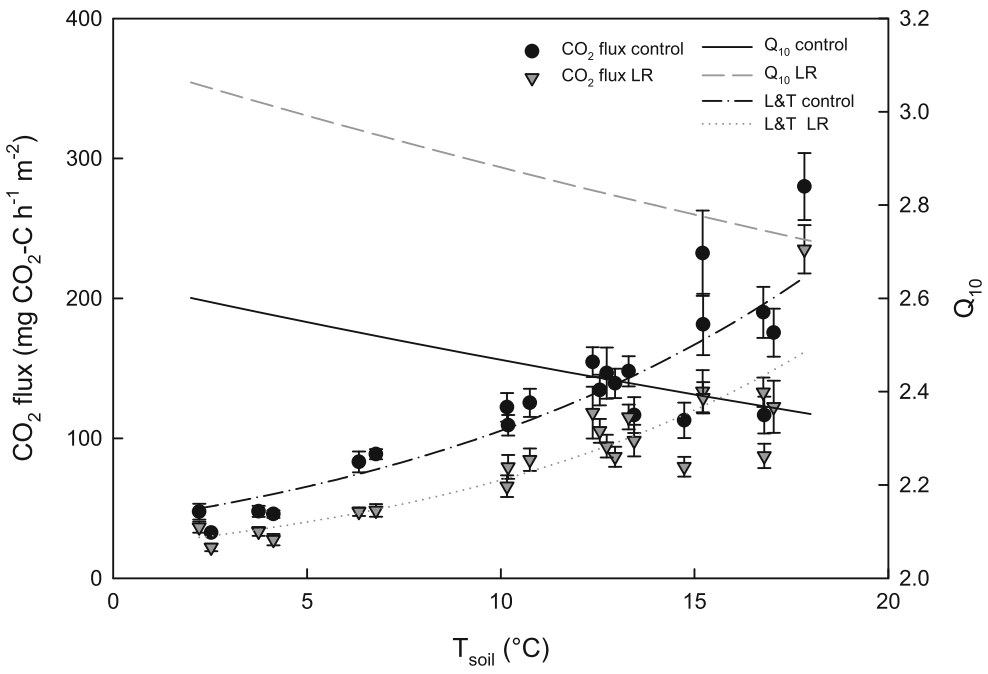




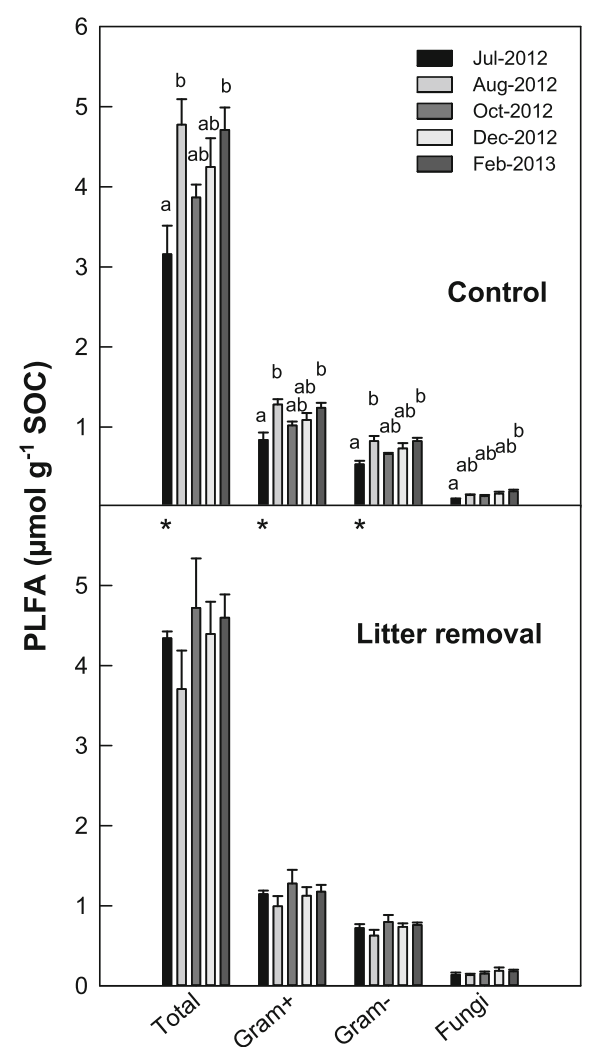

Fig. 3 Concentrations of total, gram + bacterial, gram- bacterial and fungal phospholipid fatty acid (PLFA) markers in soil from control (upper panel) and litter-removal (lower panel) plots from July 2012 to February 2013. Asterisks indicate significant differences between treatments at the respective time points ( $t$-test; *, $P<0.05)$, letters indicate significant differences between time points for the respective treatment (one-way ANOVA, no time effect for litter removal was found). Given are means \pm SE $(n=3)$

by the constrained variability of the CCA was $67.9 \%$, split in $41.1 \%$ and $17.6 \%$ for the CCA1 and CCA2, respectively. Both CCA1 and CCA2 were significant $(P<0.001$, permutation test). The

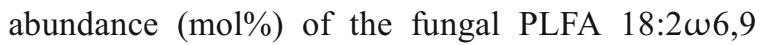
was positively related to $\mathrm{VWC}$ and $\mathrm{PO}_{4}{ }^{3-}$ and negatively to $\mathrm{C}_{\text {mic }}$ and $\mathrm{N}_{\text {mic }}$, SOC, TN and $\mathrm{NO}_{3}{ }^{-}$ (Fig. 4a). The abundance of bacterial PLFAs (gram+, gram- and general bacteria) was positively related to soil temperature, $\mathrm{NO}_{3}{ }^{-}, \mathrm{NH}_{4}{ }^{+}, \mathrm{SOC}$ and $\mathrm{TN}$, and negatively to $\mathrm{pH}, \mathrm{VWC}$ and DaLR. PLFA scores (Fig. 4b), an indicator of species composition, showed that differences between treatments were only significant at the first two sampling dates. There was a clear separation between sampling time points showing a shift from July 2012 to February 2013.

\section{Discussion}

Soil properties

We hypothesized that litter removal affects concentrations of mobile $\mathrm{C}$ and nutrients in the mineral soil (Hypothesis i) because litter is a major source for soil nutrients, and depolymerization of litter compounds yields mobile molecules like sugars, phenols, amino acids and $\mathrm{NO}_{3}{ }^{-}$which are water-soluble and prone to leaching into the mineral soil. However, our results did not confirm this assumption. We only found a temporary increase of $\mathrm{NH}_{4}{ }^{+}$at the first sampling date, which presumably was a disturbance effect of the litter removal in the week before. Surprisingly, we found no changes in $\mathrm{NO}_{3}{ }^{-}, \mathrm{NH}_{4}{ }^{+}, \mathrm{PO}_{4}{ }^{3-}$ or WSS at any other sampling date. Similar results were reported by $\mathrm{Xu}$ et al. (2013), who conducted a meta-analysis on 70 in situ litter manipulation experiments across various ecosystems and climatic regions. They discovered that litter removal had no influence on concentrations of DOC, extractable inorganic $\mathrm{N}$ (EIN) and extractable $\mathrm{P}$ in mineral soils of temperate forests. Litter-derived DOC can be quickly mineralized by soil microbial communities (Kalbitz et al. 2003) and adsorbed to the soil mineral matrix (Guelland et al. 2013). Mobile $\mathrm{N}$ forms like $\mathrm{NO}_{3}{ }^{-}$, $\mathrm{NH}_{4}{ }^{+}$and amino acids are quickly immobilized by microorganisms and plant roots in the mineral soil (Inselsbacher et al. 2010). Litter-derived P can be adsorbed to the mineral matrix (Tiessen 2008) or taken up by plant roots before it enters the mineral soil (Attiwill and Adams 1993). It is therefore possible that because DOC, inorganic $\mathrm{N}$ and $\mathrm{P}$ were either adsorbed to the mineral matrix or turned over quickly, in the present study changes in these pools caused by litter manipulation were not detectable with standard soil extraction methods that target plant-accessible compounds.

Soil greenhouse gas fluxes

In the present study, litter removal significantly changed soil fluxes of all three measured GHGs. In agreement with hypothesis ii, $\mathrm{CO}_{2}$ fluxes were reduced by $29.9 \%$ in LR plots, and litter-induced contribution to total $\mathrm{CO}_{2}$ flux ranged from 15.6 to $46.1 \%$. This is in line with previous studies that have reported a litter-induced contribution of 5-45\% total soil $\mathrm{CO}_{2}$ flux in temperate forests (Borken and Beese 2005; Bowden et al. 1993; 


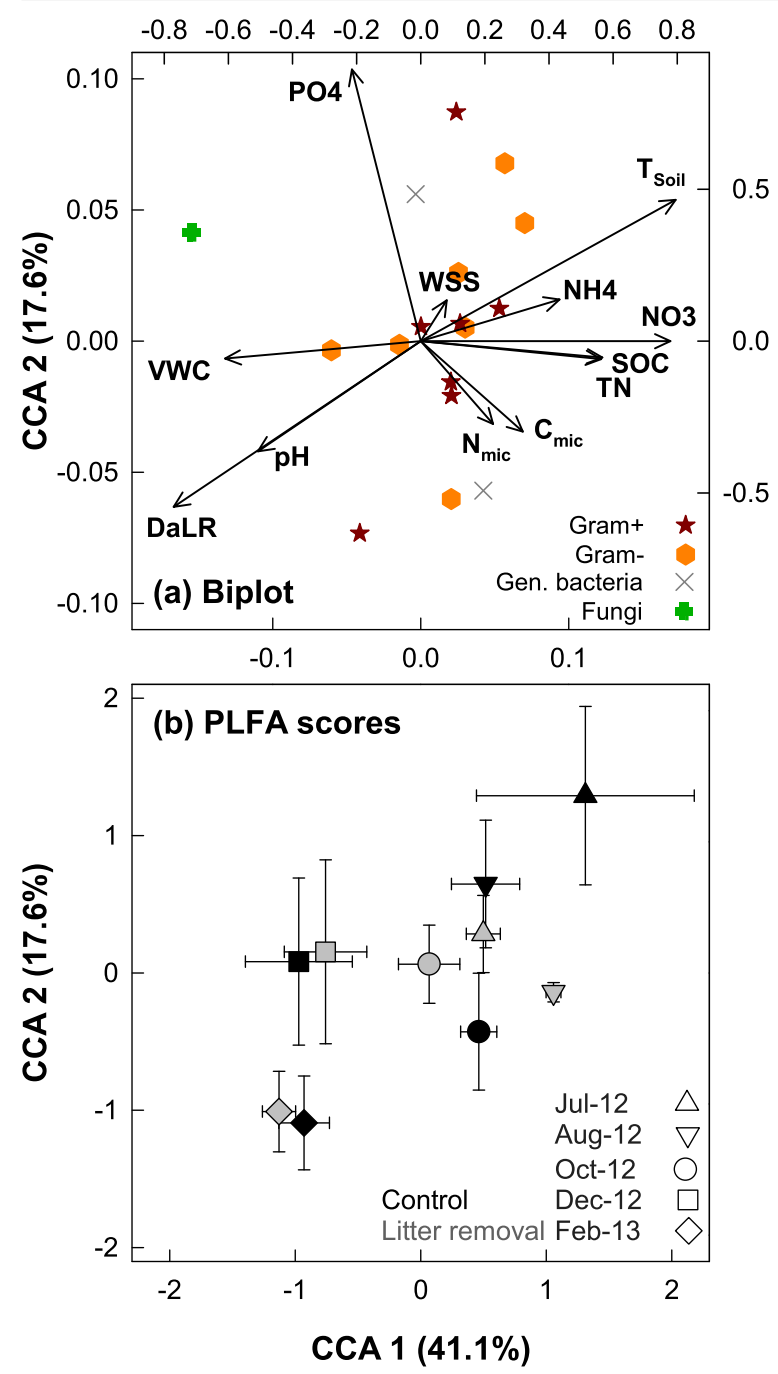

Fig. 4 Influence of soil parameters and time on microbial community composition as determined by canonical correspondence analysis (CCA). a, Biplot with microbial groups (gram+, grampositive bacterial PLFAs; gram-, gram-negative bacterial PLFAs; gen. bacteria, unspecific bacterial PLFAs; fungi, fungal PLFA $18: 2 \omega 6,9)$ and explaining environmental variables as factor loadings (arrows). We used relative abundances (\%mol) of single PLFA markers as soil microbial community matrix, and soil parameters $\left(\mathrm{pH}\right.$; VWC, soil volumetric water content; $\mathrm{T}_{\text {Soil }}$, soil temperature; SOC, soil organic carbon; $\mathrm{TN}$, total nitrogen; $\mathrm{C}_{\text {mic }}$, microbial carbon; $\mathrm{N}_{\text {mic }}$, microbial nitrogen; $\mathrm{NH} 4$, ammonium-N; NO3, nitrate-N; PO4, phosphate-P; WSS, water-soluble sugars) and time (DaLR, day after litter removal) as constraining variables. b, Distribution of samples collected at 5 time points in 2 treatments according to the PLFA species matrix (mean $\pm 95 \% \mathrm{CI}, n=3$ )

Vose and Bolstad 2007). High contributions of the litter layer to total soil $\mathrm{CO}_{2}$ fluxes can be explained by the active decomposition of litter material, which is rich in easily available $C$ and nutrients. In the present study, the amount of $\mathrm{C}$ stored in the litter layer was estimated to be $0.55 \mathrm{~kg} \mathrm{C} \mathrm{m}^{-2}$, which represents $21 \%$ of the total soil C stock (litter-C + mineral soil-C in $0-5 \mathrm{~cm}$ soil depth). Carbon dioxide fluxes of both LR and control plots were closely related to $\mathrm{T}_{\text {soil }}$. Temperature sensitivity as expressed by $\mathrm{Q}_{10}$ was higher in LR plots, indicating that $\mathrm{CO}_{2}$ flux from mineral soil was more temperaturesensitive than litter-induced $\mathrm{CO}_{2}$ flux. Similar results were reported by Creamer et al. (2015) for an Australian native woodland, who reported that the temperature sensitivity of litter-C was lower than that of soil-C. This supports the theory that with decreasing substrate quality, temperature sensitivity of soil $\mathrm{CO}_{2}$ flux increases because more enzymatic steps are required to break down low-quality organic matter, and each of these steps in turn is temperature sensitive due to microbial enzyme kinetics (Bosatta and Ågren 1999; Fierer et al. 2005; Yuste et al. 2007). However, because we have not tested the temperature sensitivity of litterinduced $\mathrm{CO}_{2}$ flux alone, we cannot prove this assumption.

Methane fluxes were negative during the entire study period, which indicates constant uptake of atmospheric $\mathrm{CH}_{4}$ by soils of both treatments. Well-aerated soils of upland forests have been shown to act mostly as $\mathrm{CH}_{4}$ sinks due to high activity of methanotrophic bacteria that oxidize $\mathrm{CH}_{4}$ under aerobic conditions to produce energy (Blais et al. 2005; Le Mer and Roger 2001). In our study, litter removal increased average $\mathrm{CH}_{4}$ uptake by $16.0 \%$, which corroborates hypothesis iii. We found highest litter-induced contributions to total $\mathrm{CH}_{4}$ fluxes between November and January, where $\mathrm{CH}_{4}$ uptake was between 19.9 and $100.9 \%$ higher in LR plots than in control plots. This period was characterized by steadily increasing VWC due to frequent rainfalls. Soil VWC was similar in both treatments at all sampling dates and can therefore not explain different $\mathrm{CH}_{4}$ fluxes in the two treatments. However, we assume that the wet litter layer itself acted as a barrier against diffusion of atmospheric $\mathrm{CH}_{4}$ into the soil and, therefore, reduced $\mathrm{CH}_{4}$ uptake in control plots. This has also been suggested for subtropical forests (Wang et al. 2013) and temperate forests, especially broad-leaved forests like beech (Brumme and Borken 1999). Nevertheless, we cannot test this assumption because we measured only net $\mathrm{CH}_{4}$ fluxes but not $\mathrm{CH}_{4}$ diffusion. Furthermore, leachates such as monoterpenes from litter have been described to suppress $\mathrm{CH}_{4}$ consumption in mineral soils (Amaral and Knowles 1997, 1998), from which we conclude that 
litter removal increases $\mathrm{CH}_{4}$ consumption and that the inhibitory effect of the litter layer might be stronger in the wet season. We found a positive correlation between $\mathrm{CH}_{4}$ fluxes and VWC in control plots, which indicates lower $\mathrm{CH}_{4}$ uptake rates (i.e. less negative $\mathrm{CH}_{4}$ fluxes) at high VWC in the presence of an intact litter layer. If soil VWC is high, soil $\mathrm{O}_{2}$ levels are low, which can reduce $\mathrm{CH}_{4}$ oxidation by methanotrophic bacteria and decrease $\mathrm{CH}_{4}$ uptake rates.

In accordance with hypothesis iv, litter removal decreased average $\mathrm{N}_{2} \mathrm{O}$ fluxes by $117.5 \%$ and turned soils from $\mathrm{N}_{2} \mathrm{O}$ sources $\left(5.72 \mu \mathrm{g} \mathrm{N} \mathrm{N}_{2} \mathrm{O}-\mathrm{N} \mathrm{h}^{-1}\right.$ $\mathrm{m}^{-2}$ in controls) to moderate $\mathrm{N}_{2} \mathrm{O}$ sinks $(-1.00 \mu \mathrm{g}$ $\mathrm{N}_{2} \mathrm{O}-\mathrm{N} \mathrm{h}^{-1} \mathrm{~m}^{-2}$ in LR). Nitrous oxide uptake by soils of various ecosystems has frequently been reported and was reviewed by Schlesinger (2013) but has also been challenged as measurement error (Cowan et al. 2014). In the present study, three $\mathrm{N}_{2} \mathrm{O}$ emission peaks were measured in control plots between August and October, which all coincided with rapid increases in soil VWC due to heavy rainfalls after dry periods. Interestingly, these peaks only occurred in control plots, although VWC was not different between treatments. It is, however, possible that after rainfall the wet litter layer acted as diffusion barrier for $\mathrm{O}_{2}$ and created anoxic microsites in control plots where $\mathrm{N}_{2} \mathrm{O}$ was produced. Another possible explanation is that increased runoff due to litter removal led to higher local aeration and therefore reduction of $\mathrm{N}_{2} \mathrm{O}$ to $\mathrm{N}_{2}$ in aerobic microsites, although VWC was not lower in LR plots. It is also conceivable that $\mathrm{N}_{2} \mathrm{O}$ was produced in the wet litter layer itself, which is rich in $\mathrm{C}$ and $\mathrm{N}$ to support nitrification and denitrification, and which after rainfalls might contain enough moisture to form anoxic microsites. Dong et al. (1998) reported that $50 \%$ of emitted $\mathrm{N}_{2} \mathrm{O}$ in a German beech forest originated from the leaf litter/humus layer. In the present study, we observed high $\mathrm{N}_{2} \mathrm{O}$ emissions from both control and LR plots in January 2013. This could be explained by the presence of a thin snow and ice layer that might have acted as diffusion barrier against $\mathrm{O}_{2}$ and thus created anoxic conditions in both treatments. This was corroborated by low $\mathrm{CH}_{4}$ consumption rates in control and LR plots at this particular date. Furthermore, although negative soil temperatures in $5 \mathrm{~cm}$ depth were not recorded on any of the gas sampling dates, a preceding freeze-thaw event on the soil surface could have led to elevated $\mathrm{N}_{2} \mathrm{O}$ fluxes on this date, as has been observed earlier (e.g., van Bochove et al. 2000; Teepe et al. 2001; Wolf et al. 2012; Butterbach-Bahl et al. 2013). We found no correlations between $\mathrm{N}_{2} \mathrm{O}$ fluxes and $\mathrm{T}_{\text {soil }}$ or VWC, which indicates that $\mathrm{N}_{2} \mathrm{O}$ formation and consumption was limited by low $\mathrm{N}$ content and acidic $\mathrm{pH}$ at our study site, as has also been reported for other temperate forests (Butterbach-Bahl et al. 1998; Castro et al. 1992; Hahn et al. 2000).

Soil microbial community composition

Our data suggest an initial transient effect of litter removal on soil microbial abundance and community composition. At the first sampling 1 week after litter removal, $\mathrm{C}_{\text {mic }}$ as well as PLFAs of gram + and gram- bacteria increased in LR plots, whereas we found no difference between treatments at the consecutive samplings. This immediate increase in bacterial PLFAs could be a consequence of the litter removal at the beginning of the experiment. Although we took great care to completely remove the litter layer, we cannot rule out that some remains of fine debris were left on the LR plots. This remaining fine debris would probably be slightly damaged and also well-aerated because the litter layer on top was removed. Because fragmentation increases litter decomposability (David and Handa 2010; Hassall et al. 1987), this might have led to a flush of available $\mathrm{C}$ and nutrients, which could have supported fast-growing bacteria and led to increased concentrations of bacterial PLFAs at the first sampling. In the long term, however, we did not find any influence of litter removal on the contribution of fungi to the soil microbial community, which refutes hypothesis v. This is in line with a study of Brant et al. (2006), which studied the influence of aboveand below-ground litter manipulation on soil microorganisms at 3 different sites in the USA and Hungary. They reported no influence of aboveground litter removal after 4, 7 and 13 years, respectively. Similar to our results, Creamer et al. (2015) reported that bacterial community composition analysed by terminal restriction fragment length polymorphism (T-RFLP) was not different in mineral soils compared to mineral soils mixed with preincubated eucalyptus litter. In a study that used ${ }^{14} \mathrm{C}$ labelled leaf litter, Kramer et al. (2010) discovered 
that recent ( $<4$ year old) leaf litter made up $<10 \%$ microbial-C in mineral soil of a temperate oak forest, whereas greatest inputs to microbial-C originated from roots. Our results corroborate that removal of aboveground litter does not influence microbial community composition of mineral soils within 8 months.

Similar to previous studies, we found a significant influence of seasonality on soil microbial community composition (Kaiser et al. 2010; Koranda et al. 2013; Rasche et al. 2011). From summer to winter, bacterial and fungal PLFA markers increased slightly. CCA analysis of single PLFA composition showed that differences between sampling time points were larger than between treatments. Our results indicate that seasonal differences in microbial community composition seem to be linked to soil $\mathrm{pH}, \mathrm{T}_{\text {soil }}$ and VWC. In a study in an Austrian beech forest similar to our site, Kaiser et al. (2010) also found a significant influence of soil moisture and temperature on soil microbial community composition. This seems plausible, as water availability and temperature are well-known determinants of microbial metabolism. Overall, our data confirm the importance of seasonal changes in temperature, moisture availability and soil nutrient cycling for the composition of microbial communities in temperate forest soils.

\section{Conclusions}

The litter layer contributes largely to soil GHG fluxes and influences temperature sensitivity of soil $\mathrm{CO}_{2}$ fluxes. This should be accounted for in climate change models as litter represents a major component of total $\mathrm{C}$ input to soils. Our results suggest that in the short term, the litter layer controls soil GHG fluxes mainly via physical processes and $\mathrm{C}$ chemistry and not via nutrient leaching into the mineral soil. Furthermore, our data indicate that nutrient leaching from litter does not determine microbial community composition in the mineral soil in the short term. Our results are relevant for the basic understanding of forest biogeochemical cycles and should be taken into account when assessing GHG budgets in forests.

Acknowledgments This study has been partly financed by the ECLAIRE project (FP7 282910). Sonja Leitner was funded by a $\mathrm{PhD}$ fellowship from the AXA research fund (Ref: 2012-DocUniversity of Natural Resources and Life Sciences-LEITNER S). Furthermore, we want to thank Katharina M. Keiblinger for helpful comments on the manuscript, and Ika Djukic for an introduction to PLFA analysis.

Open Access This article is distributed under the terms of the Creative Commons Attribution 4.0 International License (http:// creativecommons.org/licenses/by/4.0/), which permits unrestricted use, distribution, and reproduction in any medium, provided you give appropriate credit to the original author(s) and the source, provide a link to the Creative Commons license, and indicate if changes were made.

\section{References}

Amaral JA, Knowles R (1997) Inhibition of methane consumption in forest soils and pure cultures of methanotrophs by aqueous forest soil extracts. Soil Biol Biochem 29:1713-1720

Amaral J, Knowles R (1998) Inhibition of methane consumption in forest soils by monoterpenes. J Chem Ecol 24:723-734

Attiwill PM, Adams MA (1993) Nutrient cycling in forests. New Phytol 124:561-582

Ayres E, Steltzer H, Simmons BL, Simpson RT, Steinweg JM, Wallenstein MD, Mellor N, Parton WJ, Moore JC, Wall DH (2009) Home-field advantage accelerates leaf litter decomposition in forests. Soil Biol Biochem 41:606-610. doi:10. 1016/j.soilbio.2008.12.022

Baath E (2003) The use of neutral lipid fatty acids to indicate the physiological conditions of soil fungi. Microb Ecol 45:373383. doi:10.1007/s00248-003-2002-y

Barton L, Kiese R, Gatter D, Butterbach-Bahl K, Buck R, Hinz C, Murphy DV (2008) Nitrous oxide emissions from a cropped soil in a semi-arid climate. Glob Chang Biol 14:177-192

Benjamini Y, Hochberg Y (1995) Controlling the false discovery rate: a practical and powerful approach to multiple testing. $\mathrm{J}$ R Stat Soc B Methodol 289-300

Blais A-M, Lorrain S, Tremblay A (2005) Greenhouse gas fluxes $(\mathrm{CO} 2, \mathrm{CH} 4$ and $\mathrm{N} 2 \mathrm{O})$ in forests and wetlands of boreal, temperate and tropical regions. In: Tremblay A, Varfalvy L, Roehm C, Garneau M (eds) Greenhouse gas emissions fluxes and processes. Springer, Berlin Heidelberg

Bodelier PLE, Laanbroek HJ (2004) Nitrogen as a regulatory factor of methane oxidation in soils and sediments. FEMS Microbiol Ecol 47:265-277. doi:10.1016/s0168-6496(03) 00304-0

Borken W, Beese F (2005) Soil respiration in pure and mixed stands of European beech and Norway spruce following removal of organic horizons. Can J For Res 35:2756-2764

Bosatta E, Ågren GI (1999) Soil organic matter quality interpreted thermodynamically. Soil Biol Biochem 31:1889-1891

Bowden RD, Nadelhoffer KJ, Boone RD, Melillo JM, Garrison JB (1993) Contributions of aboveground litter, belowground litter, and root respiration to total soil respiration in a temperate mixed hardwood forest. Can J For Res 23:1402-1407. doi:10.1139/x93-177

Brandstätter C, Keiblinger K, Wanek W, Zechmeister-Boltenstern S (2013) A closeup study of early beech litter decomposition: potential drivers and microbial interactions on a changing substrate. Plant Soil 371:139-154. doi:10.1007/s11104-0131671-7 
Brant JB, Myrold DD, Sulzman EW (2006) Root controls on soil microbial community structure in forest soils. Oecologia 148 : 650-659. doi:10.1007/s00442-006-0402-7

Brumme R, Borken W (1999) Site variation in methane oxidation as affected by atmospheric deposition and type of temperate forest ecosystem. Glob Biogeochem Cycles 13:493-501. doi:10.1029/1998gb900017

Butterbach-Bahl K, Gasche R, Huber C, Kreutzer K, Papen H (1998) Impact of $\mathrm{N}$-input by wet deposition on $\mathrm{N}$-trace gas fluxes and CH4-oxidation in spruce forest ecosystems of the temperate zone in Europe. Atmos Environ 32:559-564

Butterbach-Bahl K, Baggs EM, Dannenmann M, Kiese R, Zechmeister-Boltenstern S (2013) Nitrous oxide emissions from soils: how well do we understand the processes and their controls? Philos Trans R Soc B Biol Sci 368. doi: 10. 1098/rstb.2013.0122

Castro MS, Steudler PA, Melillo JM, Aber JD, Millham S (1992) Exchange of $\mathrm{N} 2 \mathrm{O}$ and $\mathrm{CH} 4$ between the atmosphere and soils in spruce-fir forests in the northeastern united states. Biogeochemistry 18:119-135. doi:10. 1007/bf00003273

Chadwick DR, Cardenas L, Misselbrook TH, Smith KA, Rees RM, Watson CJ, McGeough KL, Williams JR, Cloy JM, Thorman RE, Dhanoa MS (2014) Optimizing chamber methods for measuring nitrous oxide emissions from plotbased agricultural experiments. Eur J Soil Sci 65:295-307. doi:10.1111/ejss. 12117

Conrad R (1996) Soil microorganisms as controllers of atmospheric trace gases ( $\mathrm{H} 2, \mathrm{CO}, \mathrm{CH} 4, \mathrm{OCS}, \mathrm{N} 2 \mathrm{O}$, and $\mathrm{NO})$. Microbiol Mol Biol Rev 60:609-640

Cowan N, Famulari D, Levy P, Anderson M, Reay D, Skiba U (2014) Investigating uptake of N2O in agricultural soils using a high-precision dynamic chamber method. Atmos Meas Tech 7:4455-4462

Creamer CA, de Menezes AB, Krull ES, Sanderman J, NewtonWalters R, Farrell M (2015) Microbial community structure mediates response of soil $\mathrm{C}$ decomposition to litter addition and warming. Soil Biol Biochem 80:175-188. doi:10.1016/j. soilbio.2014.10.008

Dalal RC, Allen DE (2008) Greenhouse gas fluxes from natural ecosystems. Aust J Bot 56:369-407. doi:10.1071/bt07128

David JF, Handa IT (2010) The ecology of saprophagous macroarthropods (millipedes, woodlice) in the context of global change. Biol Rev 85:881-895

Djukic I, Zehetner F, Mentler A, Gerzabek MH (2010) Microbial community composition and activity in different Alpine vegetation zones. Soil Biol Biochem 42:155-161. doi:10.1016/j. soilbio.2009.10.006

Djukic I, Zehetner F, Watzinger A, Horacek M, Gerzabek MH (2013) In situ carbon turnover dynamics and the role of soil microorganisms therein: a climate warming study in an Alpine ecosystem. FEMS Microbiol Ecol 83:112-124. doi: 10.1111/j.1574-6941.2012.01449.x

Dong Y, Scharffe D, Lobert JM, Crutzen PJ, Sanhueza E (1998) Fluxes of $\mathrm{CO} 2, \mathrm{CH} 4$ and $\mathrm{N} 2 \mathrm{O}$ from a temperate forest soil: the effects of leaves and humus layers. Tellus Ser B Chem Phys Meteorol 50:243-252. doi:10.1034/j.1600-0889.1998. t01-2-00003.x

FAO (2010) Global Forests Resources Assessment 2010 - Main report. FAO For Pap 163:44-48
Fierer N, Craine JM, McLauchlan K, Schimel JP (2005) Litter quality and the temperature sensitivity of decomposition. Ecology 86:320-326

Frostegård A, Tunlid A, Bååth E (1991) Microbial biomass measured as total lipid phosphate in soils of different organic content. J Microbiol Methods 14:151-163. doi:10.1016/ 0167-7012(91)90018-L

Groffman P, Butterbach-Bahl K, Fulweiler R, Gold A, Morse J, Stander E, Tague C, Tonitto C, Vidon P (2009) Challenges to incorporating spatially and temporally explicit phenomena (hotspots and hot moments) in denitrification models. Biogeochemistry 93:49-77. doi:10.1007/s10533-008-92775

Guelland K, Esperschutz J, Bornhauser D, Bernasconi SM, Kretzschmar R, Hagedorn F (2013) Mineralisation and leaching of C from C-13 labelled plant litter along an initial soil chronosequence of a glacier forefield. Soil Biol Biochem 57:237-247. doi:10.1016/j.soilbio.2012.07.002

Hahn M, Gartner K, Zechmeister-Boltenstern S (2000) Greenhouse gas emissions $\left(\mathrm{N}_{2} \mathrm{O}, \mathrm{CO}_{2}\right.$ and $\left.\mathrm{CH}_{4}\right)$ from three forest soils near Vienna (Austria) with different water and nitrogen regimes. Bodenkultur 51:115-125

Hassall M, Turner J, Rands M (1987) Effects of terrestrial isopods on the decomposition of woodland leaf litter. Oecologia 72 : 597-604

Hood-Nowotny R, Hinko-Najera Umana N, Inselbacher E, Oswald-Lachouani P, Wanek W (2010) Alternative methods for measuring inorganic, organic, and total dissolved nitrogen in soil. Soil Sci Soc Am J 74:1018-1027. doi:10.2136/ sssaj2009.0389

Inselsbacher E, Hinko-Najera Umana N, Stange FC, Gorfer M, Schueller E, Ripka K, Zechmeister-Boltenstern S, HoodNovotny R, Strauss J, Wanek W (2010) Short-term competition between crop plants and soil microbes for inorganic $\mathrm{N}$ fertilizer. Soil Biol Biochem 42:360-372. doi:10.1016/j. soilbio.2009.11.019

IPCC (2013) Climate change 2013: the physical science basis. Contribution of working group $i$ to the fifth assessment report of the intergovernmental panel on climate change. Cambridge University Press, Cambridge

IPCC (2014) Summary for policymakers. In: Edenhofer O, PichsMadruga R, Sokona Y, Farahani E, Kadner S, Seyboth K, Adler A, Baum I, Brunner S, Eickemeier P, Kriemann B, Savolainen J, Schlömer S, von Stechow C, Zwickel T, Minx JC (eds) Climate change 2014: mitigation of climate change contribution of working group iii to the fifth assessment report of the intergovernmental panel on climate change. Cambridge University Press, Cambridge

Kaiser C, Koranda M, Kitzler B, Fuchslueger L, Schnecker J, Schweiger P, Rasche F, Zechmeister-Boltenstern S, Sessitsch A, Richter A (2010) Belowground carbon allocation by trees drives seasonal patterns of extracellular enzyme activities by altering microbial community composition in a beech forest soil. New Phytol 187:843-858

Kalbitz K, Schmerwitz J, Schwesig D, Matzner E (2003) Biodegradation of soil-derived dissolved organic matter as related to its properties. Geoderma 113:273-291

Keiblinger KM, Hall EK, Wanek W, Szukics U, Hammerle I, Ellersdorfer G, Bock S, Strauss J, Sterflinger K, Richter A, Zechmeister-Boltenstern S (2010) The effect of resource 
quantity and resource stoichiometry on microbial carbon-useefficiency. FEMS Microbiol Ecol 73:430-440

Koranda M, Kaiser C, Fuchslueger L, Kitzler B, Sessitsch A, Zechmeister-Boltenstern S, Richter A (2013) Seasonal variation in functional properties of microbial communities in beech forest soil. Soil Biol Biochem 60:95-104. doi:10.1016/ j.soilbio.2013.01.025

Kramer C, Trumbore S, Froberg M, Dozal LMC, Zhang DC, Xu XM, Santos GM, Hanson PJ (2010) Recent ( $<4$ year old) leaf litter is not a major source of microbial carbon in a temperate forest mineral soil. Soil Biol Biochem 42:1028-1037. doi:10. 1016/j.soilbio.2010.02.021

Le Mer J, Roger P (2001) Production, oxidation, emission and consumption of methane by soils: a review. Eur J Soil Biol 37:25-50. doi:10.1016/s1164-5563(01)01067-6

Lloyd J, Taylor J (1994) On the temperature dependence of soil respiration. Funct Ecol 315-323

Macdonald JA, Skiba U, Sheppard LJ, Ball B, Roberts JD, Smith KA, Fowler D (1997) The effect of nitrogen deposition and seasonal variability on methane oxidation and nitrous oxide emission rates in an upland spruce plantation and moorland. Atmos Environ 31:3693-3706. doi:10.1016/s1352-2310(97) 00265-3

Madritch MD, Lindroth RL (2011) Soil microbial communities adapt to genetic variation in leaf litter inputs. Oikos 120 : 1696-1704. doi:10.1111/j.1600-0706.2011.19195.x

Metcalfe D, Meir P, Aragao L, Malhi Y, Da Costa A, Braga A, Gonçalves P, De Athaydes J, De Almeida S, Williams M (2007) Factors controlling spatio-temporal variation in carbon dioxide efflux from surface litter, roots, and soil organic matter at four rain forest sites in the eastern Amazon. J Geophys Res Biogeosci 2005-2012:112

Oksanen J, Blanchet F, Kindt RG, Legendre P, Minchin PR, O'Hara RB, Simpson GL, Solymnos P, Henry M, Stevens H, Wagner H (2014) Vegan: community ecology package. R package version 2.1-41/r2867. http://R-Forge.R-project.org/ projects/vegan/

Parkin T, Venterea R, Hargreaves S (2012) Calculating the detection limits of chamber-based soil greenhouse gas flux measurements. J Environ Qual 41:705-715

Peichl M, Arain MA, Ullah S, Moore TR (2010) Carbon dioxide, methane, and nitrous oxide exchanges in an age-sequence of temperate pine forests. Glob Chang Biol 16:2198-2212. doi: 10.1111/j.1365-2486.2009.02066.x

Rasche F, Knapp D, Kaiser C, Koranda M, Kitzler B, ZechmeisterBoltenstern S, Richter A, Sessitsch A (2011) Seasonality and resource availability control bacterial and archaeal communities in soils of a temperate beech forest. ISME J 5:389-402. doi:10.1038/ismej.2010.138

Reith F, Drake HL, Kusel K (2002) Anaerobic activities of bacteria and fungi in moderately acidic conifer and deciduous leaf litter. FEMS Microbiol Ecol 41:27-35. doi:10.1111/j.15746941.2002.tb00963.x

Schimel JP, Gulledge J (1998) Microbial community structure and global trace gases. Glob Chang Biol 4:745-758

Schinner F, Von Mersi W (1990) Xylanase-, CM-cellulase-and invertase activity in soil: an improved method. Soil Biol Biochem 22:511-515

Schinner F, Öhlinger R, Kandeler E, Margesin R (1996) Methods in soil biology. Springer Verlag, Berlin
Schlesinger WH (2013) An estimate of the global sink for nitrous oxide in soils. Glob Chang Biol 19:2929-2931. doi:10.1111/ gcb.12239

Schneider T, Keiblinger KM, Schmid E, Sterflinger-Gleixner K, Ellersdorfer G, Roschitzki B, Richter A, Eberl L, Zechmeister-Boltenstern S, Riedel K (2012) Who is who in litter decomposition? Metaproteomics reveals major microbial players and their biogeochemical functions. ISME J. doi: 10.1038/ismej.2012.11

Slaughter SL, Ellis PR, Butterworth PJ (2001) An investigation of the action of porcine pancreatic $\alpha$-amylase on native and gelatinised starches. Biochim Biophys Acta Gen Subj 1525: 29-36. doi:10.1016/S0304-4165(00)00162-8

Smith KA, Dobbie KE, Ball BC, Bakken LR, Sitaula BK, Hansen S, Brumme R, Borken W, Christensen S, Prieme A, Fowler D, Macdonald JA, Skiba U, Klemedtsson L, KasimirKlemedtsson A, Degorska A, Orlanski P (2000) Oxidation of atmospheric methane in Northern European soils, comparison with other ecosystems, and uncertainties in the global terrestrial sink. Glob Chang Biol 6:791-803. doi:10.1046/j. 1365-2486.2000.00356.x

Steudler PA, Bowden RD, Melillo JM, Aber JD (1989) Influence of nitrogen-fertilization on methane uptake in temperate forest soils. Nature 341:314-316. doi:10.1038/341314a0

Teepe R, Brumme R, Beese F (2001) Nitrous oxide emissions from soil during freezing and thawing periods. Soil Biol Biochem 33:1269-1275. doi:10.1016/S0038-0717(01) 00084-0

Tiessen H (2008) Phosphorus in the global environment. The ecophysiology of plant-phosphorus interactions. Springer

Tuomi M, Vanhala P, Karhu K, Fritze H, Liski J (2008) Heterotrophic soil respiration - Comparison of different models describing its temperature dependence. Ecol Model 211:182-190. doi:10.1016/j.ecolmodel.2007.09.003

Unteregelsbacher S, Gasche R, Lipp L, Sun W, Kreyling O, Geitlinger H, Kögel-Knabner I, Papen H, Kiese R, Schmid HP (2013) Increased methane uptake but unchanged nitrous oxide flux in montane grasslands under simulated climate change conditions. Eur J Soil Sci 64:586-596

van Bochove E, Prevost D, Pelletier F (2000) Effects of freezethaw and soil structure on nitrous oxide produced in a clay soil. Soil Sci Soc Am J 64:1638-1643

Vose JM, Bolstad PV (2007) Biotic and abiotic factors regulating forest floor $\mathrm{CO} 2$ flux across a range of forest age classes in the southern Appalachians. Pedobiologia 50:577-587

Wang YD, Wang HM, Ma ZQ, Dai XQ, Wen XF, Liu YF, Wang ZL (2013) The litter layer acts as a moisture-induced bidirectional buffer for atmospheric methane uptake by soil of a subtropical pine plantation. Soil Biol Biochem 66:45-50. doi:10.1016/j.soilbio.2013.06.018

Wieder WR, Cleveland CC, Townsend AR (2011) Throughfall exclusion and leaf litter addition drive higher rates of soil nitrous oxide emissions from a lowland wet tropical forest. Glob Chang Biol 17:3195-3207. doi:10.1111/j.1365-2486.2011.02426.x

Wilcox RR (2005) Introduction to robust estimation and hypothesis testing, 2nd edn. Elsevier, Burlington

Wolf B, Kiese R, Chen W, Grote R, Zheng X, Butterbach-Bahl K (2012) Modeling $\mathrm{N}_{2} \mathrm{O}$ emissions from steppe in Inner Mongolia, China, with consideration of spring thaw and grazing intensity. Plant Soil 350:297-310. doi:10.1007/ s11104-011-0908-6 
Xu S, Liu LL, Sayer EJ (2013) Variability of aboveground litter inputs alters soil physicochemical and biological processes: a meta-analysis of litterfall-manipulation experiments. Biogeosciences 10:7423-7433. doi:10.5194/bg-10-7423-2013 Yuste JC, Baldocchi D, Gershenson A, Goldstein A, Misson L, Wong S (2007) Microbial soil respiration and its dependency on carbon inputs, soil temperature and moisture. Glob Chang Biol 13:2018-2035

Zelles L (1999) Fatty acid patterns of phospholipids and lipopolysaccharides in the characterisation of microbial communities in soil: a review. Biol Fertil Soils 29:111-129. doi:10.1007/ s003740050533 